Article

\title{
Relative Influence of Prior Life Stages and Habitat Variables on Dragonfly (Odonata: Gomphidae) Densities among Lake Sites
}

\author{
Alysa Remsburg \\ Unity College, 90 Quaker Hill Rd, Unity, ME 04988, USA; E-Mail: aremsburg@unity.edu; \\ Tel.: +1-207-948-3131 ext. 210; Fax: +1-207-948-6277
}

Received: 10 February 2011; in revised form: 20 March 2011 / Accepted: 24 March 2011 / Published: 14 April 2011

\begin{abstract}
Many aquatic species have discrete life stages, making it important to understand relative influences of the different habitats occupied within those populations. Although population demographics in one stage can carry over to spatially separated life stages, most studies of habitat associations have been restricted to a single life stage. Among Gomphidae dragonflies (Odonata: Anisoptera), recruitment via adult oviposition establishes initial population sizes of the aquatic larvae. However, spatial variability in larval survivorship could obscure the relationship between adult and larval densities. This study uses surveys conducted during 2005 and 2006 of Gomphidae larval, emergence, and adult stages from 22 lake sites in northern Wisconsin, USA, to investigate (1) whether the Gomphidae density of each life stage correlated spatially with that of the preceding life stage and (2) what habitat factors help explain variation in densities at each life stage. Results indicated that adult densities from the previous season helped predict densities of early-instar larvae. This finding suggests that oviposition site selection controlled the local larval distribution more than larval survivorship or movement. Late-instar larval densities helped predict densities of emerging Gomphidae later the same season, suggesting that variation in survivorship of final-instar larvae among sites is small relative to the variation in larval recruitment. This study demonstrates that locations with higher densities of odonates in the water also have higher densities of odonates on land. In addition to the densities of Gomphidae in previous life stages, water clarity helped predict larval densities, and riparian wetland vegetation helped predict emergent dragonfly densities.
\end{abstract}

Keywords: complex life history; population stage structure; Odonata; riparian habitat; insect emergence; aquatic-terrestrial linkage; spatial patterns 


\section{Introduction}

The vast majority of animal species have separate life stages that occur in different habitat types. These include vertebrates and invertebrates with stages separated by size structure (e.g., [1,2]) or by complex life cycles, in which animals undergo a succession of discrete life history phases (e.g., [3,4]). Population studies incorporating multiple life stages have traditionally excluded spatial heterogeneity (reviews by [5,6]), yet spatial variation in one life stage can affect population sizes of animals in subsequent stages (e.g., [7-11]). Only a few spatially explicit models of aquatic insect populations have included multiple life stages [12-14]. Understanding the relative influence of different life stages on population demographics can help predict how modifications to either habitat could affect animals with stage-specific habitats.

Although dragonflies (order Odonata, suborder Anisoptera) require aquatic habitat for larvae and terrestrial habitat for adults, the local abundances of dragonflies may not depend on both of these habitats equally. As with many animals, dispersal occurs during the more mobile adult stage, and this stage is most vulnerable to weather patterns [15]. While survivorship during the more vulnerable juvenile stage limits population sizes [16-19], the relative importance of larval recruitment versus recruitment to the adult stage remains unknown. A common assumption is that larval mortality rates are so high that they overwhelm any effects of adult habitat selection during oviposition. Adult oviposition establishes the initial spatial patterns of aquatic odonate abundances; larvae probably do not travel $>20 \mathrm{~m}$ in lentic systems [20,21] (but see [22]) because movement can make them vulnerable to predators $[23,24]$. However, larval survivorship may vary among sites or lakes due to heterogeneity in post-recruitment processes such as larval movement, competition, and predation [25-27]. The particularly long larval phase (semi-voltine) of temperate dragonflies could make concordance between densities of these insects at different life stages weaker than in studies of other animals. Spatial patterns of local dragonfly population abundances therefore depend on the relative importance of adult habitat site selection and the spatial heterogeneity of larval survivorship (Figure 1).

Abundance and diversity of adult Odonata increase in riparian areas with tall wetland vegetation such as sedges and bulrushes, although the underlying reasons for these patterns remain unclear [28-34]. Unlike Gomphidae in more lotic ecosystems, larvae of the Gomphus, Dromogomphus, Arigomphus species in northern Wisconsin lakes are associated with riparian sites having wetland vegetation such as sedges [35]. Mature Gomphidae perch on the ground or on vegetation to thermoregulate and watch for prey or potential mates; they oviposit directly onto the surface of open water (exophytically). The observed relationship between lacustrine Gomphus species and riparian vegetation may result from oviposition site selection [35]. As with all oviparous species, it is advantageous for adults to oviposit at sites with the greatest likelihood for survival of their eggs and larvae [36]. Because adults may not be able to assess aquatic habitat suitability, adult odonates may use emergent aquatic plants or riparian plants as proximate cues of macrophyte, substrate, water depth, prey, or predator conditions in littoral sites [30,37-39]. Alternatively, foraging odonates may be attracted to higher prey abundances in riparian areas with high structural complexity [40]. 
Figure 1. Diagram of the life history of temperate dragonflies. Dotted lines illustrate the relatively weak effects of survivorship (S) and site selection (SS) on dragonfly abundances at the designated stages. Arrows in the center indicate the correlations tested in this research, assuming that exuviae (cast-off exoskeletons) abundance indicates relative abundance of teneral dragonflies.

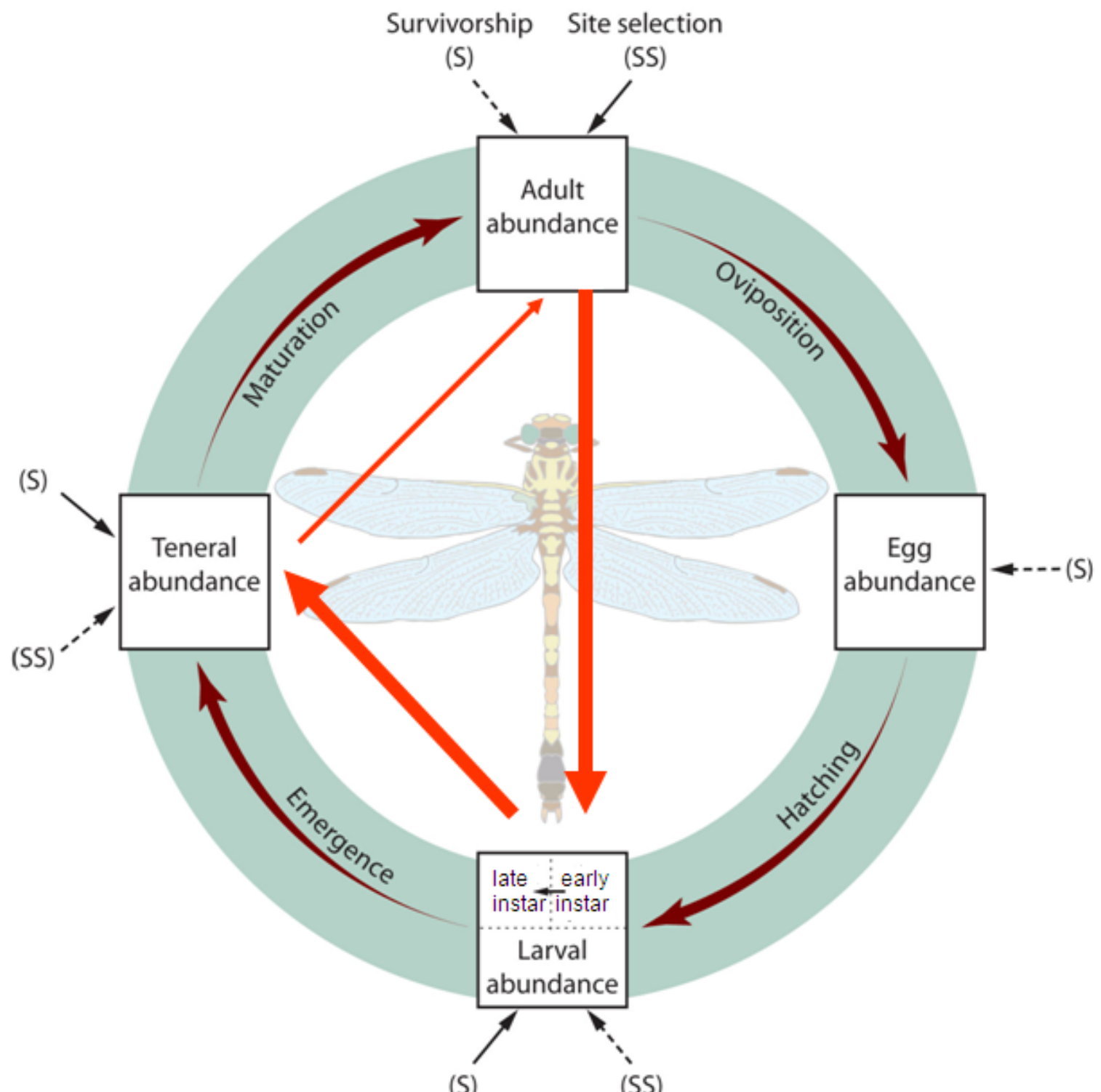

Mortality of larval Gomphidae may be as high as 95-99\% [19,41]. Lower macrophyte abundances, higher abundances of macrophyte-eating crayfish (Orconectes rusticus Girard), higher insectivorous fish abundances, or higher water clarity could each lead to higher predation on larvae [42-46] or reduced prey availability for larvae $[22,47]$. Gomphidae larvae hide from predators by burrowing in the benthic substrate, which makes these organisms less dependent on macrophytes for cover than other odonates [35,48], but Gomphus and Dromogomphus species use habitats close to macrophytes [22,49,50].

The half-hour to two-hour process of larval emergence and wing hardening is another period of particular susceptibility to predators [16,51-53], wind, rain, waves, or trampling [53,54]. Shoreline vegetation abundance can lead to greater spider abundances [55-57] and greater susceptibility of 
emerging odonates to damage from plants moving in the wind [53]. Shoreline housing development contributes to the spatial heterogeneity of emergence structures, predators, and waves. Lakeshore housing development is expanding rapidly in many areas (e.g., [58]) and is associated with simplification of vegetation structure by removal of the riparian shrub layer, floating macrophytes, and littoral coarse wood [59-62].

Based on potential drivers of odonate distributions during the adult, larval, and emergence stages, I investigated two main questions: (1) Is there concordance between the density of one Gomphidae life stage and its previous life stage at lake-level or site-level spatial scales? and (2) What habitat factors help explain variation among sites of Gomphidae larvae, emerging individuals, and adult densities? Aquatic or terrestrial habitat features relevant to each life stage may help explain the variation in Gomphidae densities not accounted for by the previous life stage.

While population demographics must be studied at the species level, relevant conclusions regarding the spatial distributions of co-occurring Gomphidae populations can be drawn from this study. Adult Gomphus species cannot be identified to species while in flight, though aerial surveys were required for estimates of adult densities over a period of time. Therefore, species level identifications were not conducted here. The study focuses entirely on Gomphidae, the only Odonata family with larvae occurring at $>50 \%$ of the 22 study sites and by far the most abundant Odonata family in the lakes studied [35]. In particular, this research examines all members of the "burrower" larval guild, therefore excluding Hagenius brevistylus Selys because it falls into a different behavioral guild [63]. Co-occurrence of the six Gomphidae species observed (Arigomphus furcifer Hagen, Dromogomphus spinosus Selys, Gomphus exilis Selys, G. fraternus Say, G. lividus Selys, and G. spicatus Hagen) appears to be high, which follows a pattern of minimal niche separation among Gomphidae species $[64,65]$. The Gomphidae species considered in this study all emerge fairly synchronously in mid-June [66,67]. The main flight period lasts between two and six weeks for most Gomphidae in this region [66]. Another study of odonate larvae at 50 lake sites in the same region [35] indicated that G. spicatus comprised $45 \%$ of the 524 burrower guild specimens collected; other relative abundances were D. spinosus $20 \%$, G. exilis $17 \%$, G. lividus $16 \%$, A. furcifer $1.4 \%$, G. fraternus $1.3 \%$.

\section{Experimental Methods}

\subsection{Study Sites}

The study took place at 22 sites on 11 lakes in Vilas County, northeastern Wisconsin, USA (Figure 2). This mixed-forest landscape contains over 1,300 glacial lakes in the $2,639 \mathrm{~km}^{2}$ county [see 68 for more details on the region]. Most of the study sites were privately owned; $14 \%$ were public property. I selected two sites per lake, separated by at least $200 \mathrm{~m}$, with similar aspect, slope, fetch, macrophyte density, benthic substrate, and hydrologic context (location relative to streams or bays) for each pair. Each site spanned $30 \mathrm{~m}$ along the shoreline by $5 \mathrm{~m}$ inland. The pair of sites on each lake included one forested site and one site with a manicured lawn. Forest sites had a dense layer of shrubs (mainly Alnus rugosa Du Roi), saplings (e.g., Betula papyrifera Marsh., Thuja occidentalis L., Acer rubrum L.), or wetland herbaceous plants (e.g., Carex retrorsa Schweinitz, Juncus effuses L., Sparganium spp.), and were generally undeveloped. Manicured lawns had mature trees but minimal understory vegetation and were associated with housing inland from the study sites. Exuvia (cast-off 
skins from emergent adults) and adult surveys in 2006 took place at 21 sites because one of the study sites (on Big St. Germain Lake) became inaccessible. Adult surveys in 2005 were restricted to 18 sites because two lakes (Lynx and Little Arbor Vitae) could not be visited during acceptable weather conditions during June.

Figure 2. Study area in Vilas County, Wisconsin, USA. The grey areas show lakes.

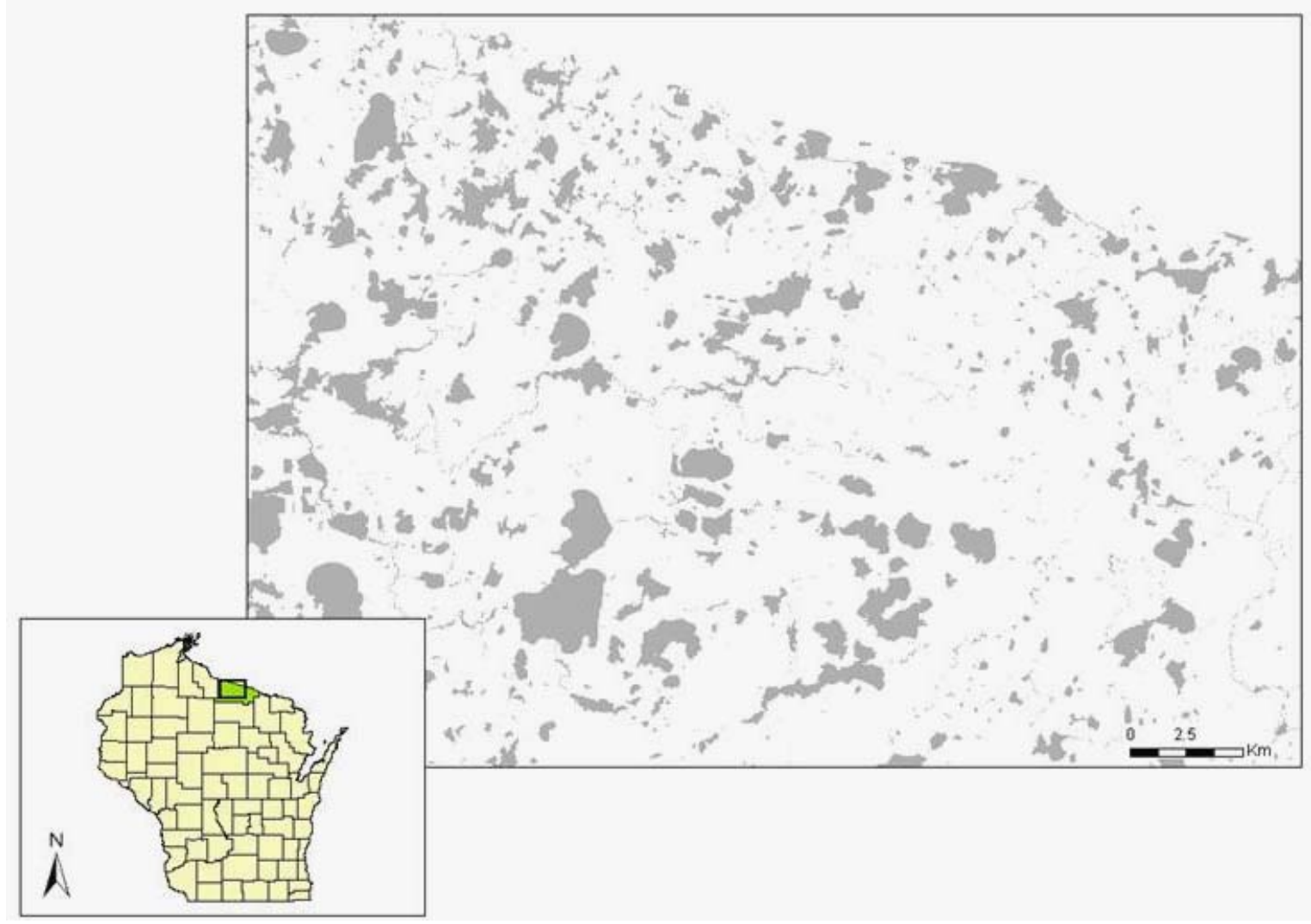

\subsection{Odonata Surveys}

For a 30-m transect paralleling the shoreline, I collected all exuviae of emerging Gomphidae within the $0.5 \mathrm{~m}$ of land nearest to water. This area included the riparian vegetation, rocks and sand. I collected exuviae on three days per site in 2005 (27 May-12 July) and four days per site in 2006 (9 June-12 July). Both sites from the same lake were visited during the same day, and survey rounds were completed for nearly all sites before beginning the next round of surveys. The last two rounds of 2005 exuviae sampling on one lake (Little Arbor Vitae) took place within four days of each other, but all other survey rounds were separated by at least a week. No surveys took place immediately after storms. Time required for searching a site exhaustively varied with understory plant density, but ranged from 15 to 45 minutes. Exuviae from all survey dates were pooled for each site.

I conducted one adult odonate survey per site between 10 June-10 July in 2005 and three adult odonate surveys per site between 15 June-21 July in 2006. Surveys were restricted to calm, sunny days between 11:00 and 16:00, when odonate flight activity is greatest [69,70]. I estimated adult odonate densities along the same $30 \mathrm{~m}$ shoreline transects using a modified 'Pollard walk' [71,72]. While walking the transect over a period of two minutes, I counted and identified all adult odonates perched or flying within $2 \mathrm{~m}$ around me (but not behind) and up to $3 \mathrm{~m}$ above the ground. If an 
individual clearly flew back and forth through the observation zone, it was only counted once. However, individuals could not be tracked if they flew out of the observation zone and later returned, so observed abundances may be slightly higher than actual abundances. The two-minute transect walk was repeated three or four times on each survey day. Adult density estimates were derived from the total number of individuals counted during survey transects divided by the total transect length (30 $\mathrm{m} \times 3$ or 4 repeated walks). Adult densities were averaged from transect walks on all three survey dates in 2006.

I collected larval odonates on one occasion per site during the first week of June 2006 in the littoral zone immediately adjacent to the 22 sites. At each site, a D-frame net was used to scoop benthic material consistently from 20 subplots evenly spaced in four different water depths: $0.25 \mathrm{~m}, 0.5 \mathrm{~m}$, $0.75 \mathrm{~m}$, and $1.0 \mathrm{~m}$. Subplot areas were separated by $2 \mathrm{~m}$ from each other and bounded by a $0.95 \mathrm{~m}$ - diameter cylinder (i.e., a trash can with the bottom cut off) that extended from the benthos to water surface. This protocol ensured that larvae within each subplot could not move out of the area while dipping the D-net [73]. For analysis I combined each site's 20 subplots, which together represent a $14 \mathrm{~m}^{2}$ area surveyed per site. The Gomphidae species surveyed generally have two- or three-year larval phases in Wisconsin. All individuals with head widths 0.5 to $3.0 \mathrm{~mm}$ were designated as "early instar" larvae, and those with head widths of 3.1 to $6.0 \mathrm{~mm}$ as "late instar" larvae.

\subsection{Habitat Variables}

The habitat variable most apparent to the human eye was presence or absence of a manicured lawn. In 2006 I estimated the relative abundances among sites of tall wetland herbaceous plants on shore ( $>0.3 \mathrm{~m}$ high; Carex, Typha, and Iris species), and littoral emergent macrophytes by measuring the length of site shoreline (out of $30 \mathrm{~m}$ ) having these vegetation categories present within $4 \mathrm{~m}$ of the water's edge (Table 1). Aquatic variables measured at the whole-lake scale included secchi depth (water clarity), insectivorous fish catch-per-unit-effort (CPUE), and rusty crayfish CPUE. All lake-level data (Table 1) were obtained from Carpenter et al. [74] and Olden et al. [75] .

\subsection{Data Analysis}

I tested effects of adult, larvae, and exuviae densities on densities of the subsequent life stages among sites (hereafter, "site-level") and lakes ("lake-level") (research question 1; Figure 1). To compare life stage densities at the lake level (lakes as replicates), I averaged Gomphidae densities from both sites at each lake and then conducted Spearman's rank correlation tests. For site-level regression analyses (sites as replicates), mixed-effects models were used. Lake was considered a random-effect term because effects of specific lakes were not of interest, but dragonfly densities at sites on the same lakes were not necessarily independent. Variance partitioning of random effects revealed what proportion of the total variation in Gomphidae densities occurred at the lake versus site level. Gomphidae densities for all life stages were log-transformed to meet normality assumptions of the linear regression. Because some values for larval and adult densities were equal to zero, the smallest non-zero density value was added before taking the $\log$, followed by adding an order-of-magnitude constant [76]. 
Table 1. Range and standard deviations in lake-level $(n=9)$ and site-level $(n=22)$ habitat variables tested as predictors for Gomphidae density.

\begin{tabular}{|c|c|c|c|}
\hline & Min & Mix & SD \\
\hline \multicolumn{4}{|l|}{ Lake-level aquatic $^{\text {a }}$} \\
\hline Perimeter $(\mathrm{km})^{\mathrm{b}}$ & 5.6 & 23.3 & 5.0 \\
\hline Area (ha) & 60.6 & 665.7 & 169 \\
\hline Morphometry ${ }^{\mathrm{c}}$ & 1.3 & 3.3 & 0.7 \\
\hline Wetland perimeter $(\%)^{d}$ & 0 & 0.2 & 0.08 \\
\hline Houses $/ \mathrm{km}$ & 5.6 & 25 & 6.3 \\
\hline Conductance $(\mu \mathrm{S} / \mathrm{cm})^{\mathrm{e}}$ & 23 & 112.5 & 34 \\
\hline Secchi depth (m) ${ }^{\mathrm{f}}$ & 2.38 & 6.25 & 1.4 \\
\hline Insectivorous fish CPUE $^{\mathrm{g}}$ & 109 & 435 & 114 \\
\hline All fish CPUE ${ }^{g}$ & 177 & 521 & 99 \\
\hline Crayfish CPUE $^{\text {h }}$ & 0 & 28.42 & 8.9 \\
\hline \multicolumn{4}{|l|}{ Site-level riparian } \\
\hline Wetland veg. length ${ }^{\mathrm{i}}$ & 0 & 30 & 10.0 \\
\hline Macrophyte length ${ }^{\mathrm{j}}$ & 0 & 30 & 6.5 \\
\hline Lawn presence /absence & 0 & 1 & 0.5 \\
\hline \multicolumn{4}{|c|}{$\begin{array}{l}{ }^{\mathrm{a}} \text { Data from Carpenter et al. }[74] ;{ }^{\mathrm{b}} \text { Lake perimeter; }{ }^{\mathrm{c}} \text { Lake perimeter divided by the perimeter of a } \\
\text { circle with the same area; }{ }^{\mathrm{d}} \text { Percent of lake perimeter in wetlands [77]; }{ }^{\mathrm{e}} \text { Specific conductance } \\
\text { (dissolved ionic content) in } \mu \text { Siemens/cm; }{ }^{\mathrm{f}} \text { A measure of water clarity; }{ }^{\mathrm{g}} \text { Catch-per-unit-effort } \\
\text { (CPUE); }{ }^{\mathrm{h}} \text { CPUE of an invasive, macrophyte-eating species, rusty crayfish (Orconectes rusticus); } \\
\text { Length of site shoreline with wetland herbaceous plants ( }>0.3 \mathrm{~m} \text { high; Carex, Typha, and Iris } \\
\text { species); }{ }^{\mathrm{i}} \text { Length of site shoreline with littoral emergent macrophytes. }\end{array}$} \\
\hline
\end{tabular}

By comparing multiple linear regressions, I tested the influence of up to six different habitat variables plus previous life stage densities on densities of adults, larvae, and exuviae at the site level. Inclusion of the previous life stage in predictive models allowed examination of habitat factors that affect only the life stage modeled (research question 2). Based on the stated hypotheses and results of research question 1, five candidate models were compared for early instar larval densities, six candidate models for 2006 exuviae densities, and seven candidate models for adult abundances in both 2005 and 2006 (Table 2). I used an information theoretic approach to compare alternative mixed-effects habitat models within the set of candidate models for each life stage. In particular, models were ranked according to the second order information criterion $\left(\mathrm{AIC}_{\mathrm{c}}\right)$ values. $\mathrm{AIC}_{\mathrm{c}}$ has a bias correction factor to help prevent over-parameterized models when sample sizes are small [78]. Relative empirical support for a model $i$ is indicated by $\Delta_{\mathrm{i}}$, the difference between $\mathrm{AIC}_{\mathrm{c}}$ for model $i$ and the smallest $\mathrm{AIC}_{\mathrm{c}}$ of the candidate models. Information theory suggests that datasets may equivalently support multiple predictive models (particularly if $\Delta_{i}<2$ ). $R^{2}$ values are presented as a measure of overall variance explained, but were not used in model selection. I used likelihood ratio tests to compare habitat models with models using only the previous life stage, thereby separating habitat from recruitment effects. All analyses were completed using R v.2.4.1 software [79], including the nlme package for mixed-effects models. 
Table 2. Mixed-effects linear regression models ${ }^{\mathrm{a}}$ using population and habitat variables to predict Gomphidae densities at lakeshore sites in northern Wisconsin. Signs in front of independent variables indicate the sign of the coefficient in the model.

\begin{tabular}{|c|c|c|c|}
\hline Fixed-effects predictors from mixed-effects models & $\mathbf{N}^{\mathrm{b}}$ & $\Delta \mathrm{AIC}_{\mathrm{c}}{ }^{\mathrm{c}}$ & Adj. $\mathbf{R}^{2}$ \\
\hline \multicolumn{4}{|l|}{2006 Larvae } \\
\hline $\log ($ early instar larvae 2006$)=+$ adults 2005 & 18 & 3.3 & 0.50 \\
\hline $\log ($ early instar larvae 2006$)=+$ adults $_{2005}-($ lake secchi $)$ & 18 & 0.0 & 0.50 \\
\hline $\log ($ early instar larvae 2006$)=+$ adults $_{2005}+$ sqrt(site macrophytes $)$ & 18 & 2.5 & 0.11 \\
\hline $\log ($ early instar larvae 2006$)=+$ adults $_{\mathbf{2 0 0 5}}-\operatorname{sqrt}($ lake crayfish $)$ & 18 & 4.0 & 0.07 \\
\hline $\log ($ early instar larvae 2006$)=+$ adults $_{\mathbf{2 0 0 5}}-$ (lake insectiv.fish $)$ & 18 & 15.5 & 0.07 \\
\hline \multicolumn{4}{|l|}{2006 Exuviae } \\
\hline $\log \left(\right.$ exuviae $\left._{2006}\right)=+\log ($ late instar larvae 2006$)$ & 21 & 1.3 & 0.74 \\
\hline $\log \left(\right.$ exuviae $\left._{2006}\right)=+\log ($ late instar larvae 2006$)+\operatorname{sqrt}($ site wetland veg. $)$ & 21 & 0.0 & 0.86 \\
\hline $\log \left(\right.$ exuviae $\left._{2006}\right)=+\log ($ late instar larvae 2006$)+($ site lawn $)$ & 21 & 5.3 & 0.74 \\
\hline $\log \left(\right.$ exuviae $\left._{\mathbf{2 0 0 6}}\right)=+\log ($ late instar larvae 2006$)-\operatorname{sqrt}($ lake crayfish $)$ & 21 & 6.2 & 0.74 \\
\hline $\log \left(\right.$ exuviae $\left._{2006}\right)=+\log ($ late instar larvae 2006$)-($ lake secchi $)$ & 21 & 6.2 & 0.74 \\
\hline $\log \left(\right.$ exuviae $\left._{2006}\right)=+\log ($ late instar larvae 2006$)-($ lake insectiv.fish $)$ & 21 & 14.4 & 0.74 \\
\hline \multicolumn{4}{|l|}{2005 Adults } \\
\hline $\log \left(\right.$ adults $\left._{\mathbf{2 0 0 5}}\right)=+\log \left(\right.$ exuviae $\left._{\mathbf{2 0 0 5}}\right)$ & 18 & 3.7 & 0.15 \\
\hline $\log \left(\right.$ adults $\left._{\mathbf{2 0 0 5}}\right)=+\log \left(\right.$ exuviae $\left._{\mathbf{2 0 0 5}}\right)-\operatorname{sqrt}($ site wetland veg. $)$ & 18 & 0.0 & 0.09 \\
\hline $\log \left(\right.$ adults $\left._{2005}\right)=+\operatorname{sqrt}($ site macrophytes $)$ & 18 & 1.6 & 0.32 \\
\hline $\log \left(\right.$ adults $\left._{2005}\right)=+\log \left(\right.$ exuvia $\left._{2005}\right)+\operatorname{sqrt}($ site macrophytes $)$ & 18 & 1.9 & 0.23 \\
\hline $\log ($ adults2005 $)=+($ site lawn $)$ & 18 & 5.7 & 0.16 \\
\hline $\log \left(\right.$ adults $\left._{\mathbf{2 0 0 5}}\right)=+\log \left(\right.$ exuviae $\left._{\mathbf{2 0 0 5}}\right)+($ site lawn $)$ & 18 & 6.0 & 0.04 \\
\hline $\log ($ adults 2005$)=-\operatorname{sqrt}($ site wetland veg. $)$ & 18 & 9.9 & 0.20 \\
\hline \multicolumn{4}{|l|}{2006 Adults } \\
\hline $\log \left(\right.$ adults $\left._{\mathbf{2 0 0 6}}\right)=+\log \left(\right.$ exuviae $\left._{\mathbf{2 0 0 6}}\right)$ & 20 & 3.4 & $<0$ \\
\hline $\log \left(\operatorname{adults}_{2006}\right)=+\operatorname{sqrt}($ site macrophytes $)$ & 20 & 0.0 & $<0$ \\
\hline $\log ($ adults 2006$)=+\operatorname{sqrt}($ site wetland veg. $)$ & 20 & 0.2 & $<0$ \\
\hline $\log ($ adults2006 $)=-($ site lawn $)$ & 20 & 1.7 & $<0$ \\
\hline $\log \left(\right.$ adults $\left._{2006}\right)=+\log \left(\right.$ exuviae $\left._{2006}\right)+\operatorname{sqrt}($ site wetland veg. $)$ & 20 & 5.7 & $<0$ \\
\hline $\log \left(\right.$ adults $\left._{\mathbf{2 0 0 6}}\right)=+\log \left(\right.$ exuviae $\left._{\mathbf{2 0 0 6}}\right)+\operatorname{sqrt}($ site macrophytes $)$ & 20 & 5.8 & $<0$ \\
\hline $\log \left(\right.$ adults $\left._{\mathbf{2 0 0 6}}\right)=+\log \left(\right.$ exuviae $\left._{\mathbf{2 0 0 6}}\right)-($ site lawn $)$ & 20 & 7.5 & $<0$ \\
\hline
\end{tabular}

${ }^{a}$ Lake was included as a random effect in each model. Only fixed-effects terms are shown here; ${ }^{b}$ Sample size varied because some sites did not have adult surveys available during the optimal flight period for Gomphidae; ${ }^{\mathrm{c}} \Delta \mathrm{AIC}_{\mathrm{c}}$ is the difference in Akaike's second-order criterion values between the model with the lowest $\mathrm{AIC}_{\mathrm{c}}$ and the stated model.

\section{Results}

All four life stages had high variability among the 22 sites sampled (Table 3). Variance partitioning revealed that nearly all of the variance in early instar larval densities occurred at the lake level, whereas late instar larvae, exuviae, and adults each had progressively smaller proportions of the variance occurring at the lake level (Table 3). 
Table 3. Sample size, mean, coefficient of variation $(\mathrm{CV})$, and percent of total variance in densities of four Gomphidae life stages occurring among two 22 sites on 11 lakes.

\begin{tabular}{lccccc}
\hline & $\begin{array}{c}\text { Sample } \\
\text { size }\end{array}$ & Mean & $\begin{array}{c}\text { CV } \\
(\%)\end{array}$ & $\begin{array}{c}\text { Site-level } \\
\text { variance (\%) }\end{array}$ & $\begin{array}{c}\text { Lake-level } \\
\text { variance (\%) }\end{array}$ \\
\hline $\mathbf{2 0 0 6}$ Early instar larvae/m $\mathbf{m}^{\mathbf{2}}$ & 22 & 0.54 & 130 & 0 & 100.0 \\
$\mathbf{2 0 0 6}$ Late instar larvae/m $\mathbf{m}^{\mathbf{2}}$ & 22 & 0.18 & 99 & 34.4 & 58.5 \\
$\mathbf{2 0 0 5}$ Exuviae/m & 22 & 2.63 & 250 & 34.5 & 58.3 \\
$\mathbf{2 0 0 6}$ Exuviae/m & 21 & 2.95 & 130 & 37.9 & 54.7 \\
$\mathbf{2 0 0 5}$ Adults/m & 18 & 0.05 & 120 & 64.1 & 27.3 \\
$\mathbf{2 0 0 6}$ Adults/m & 20 & 0.01 & 82 & 100.0 & 0.0 \\
\hline
\end{tabular}

Early instar larval densities in 2006 were positively correlated with adult densities in 2005, at both the site and lake scales (Table 4; Figure 3). At the site level, exuviae densities in 2006 were positively correlated with late instar larval densities from earlier in the same season (Table 4; Figure 4). Adult densities did not correlate with exuviae densities from the same season in 2005 or 2006.

Table 4. Results from mixed-effects linear models comparing Gomphidae life stage densities among sites $(n=22)$ and Spearman rank correlation tests comparing life stage densities among lakes $(\mathrm{n}=11)$.

\begin{tabular}{|c|c|c|c|c|}
\hline \multirow{3}{*}{$\begin{array}{l}\text { Survey Year } \\
\text { Site }\end{array}$} & Adults $\rightarrow$ Early instar & Late instar $\rightarrow$ Exuviae & \multicolumn{2}{|c|}{ Exuviae $\rightarrow$ Adults } \\
\hline & 2005 & 2006 & 2005 & 2006 \\
\hline & Adjusted $\mathrm{R}^{2}=0.50$ & Adjusted $\mathrm{R}^{2}=0.74$ & & \\
\hline & $\begin{array}{c}\mathrm{F}_{1,8}=8.9 \\
\mathrm{p}=0.02\end{array}$ & $\begin{array}{l}F_{1,9}=18.1 \\
p=0.002\end{array}$ & n.s. ${ }^{1}$ & n.s. \\
\hline Lake & $\begin{array}{l}\text { Spearman } r=0.91 \\
p<0.001\end{array}$ & n.s. & n.s. & n.s. \\
\hline
\end{tabular}

Figure 3. Larval densities of Gomphidae burrowers from nine north-temperate lakes graphed as a function of adult densities surveyed at the same sites in the previous year.

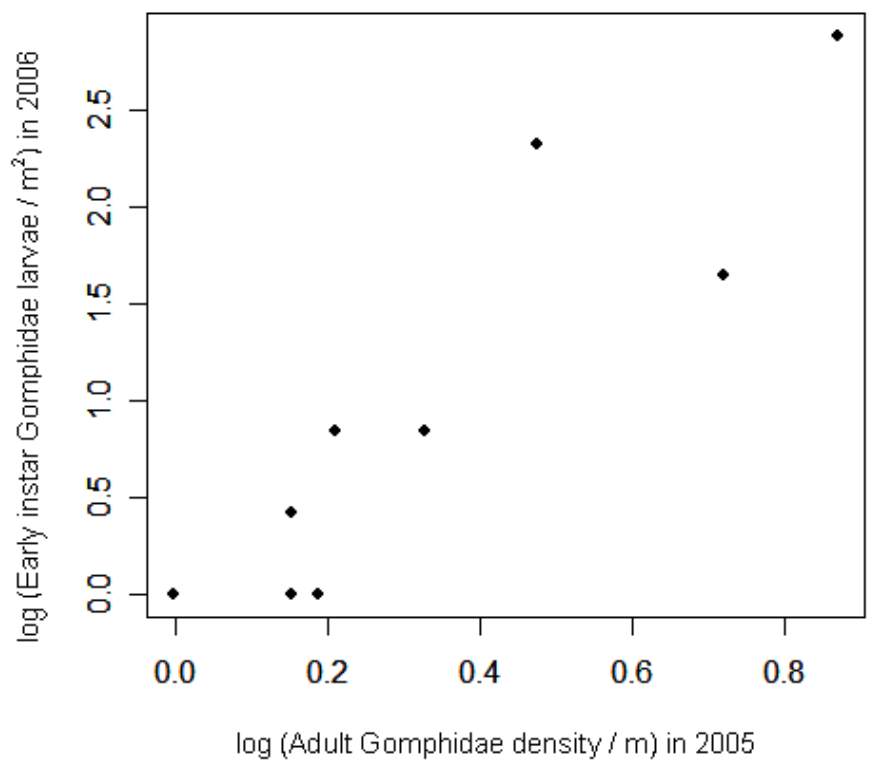


Figure 4. Gomphidae exuviae densities as a function of larval densities from the second year-class sampled earlier during the same year (2006) at 22 north-temperate lake sites.

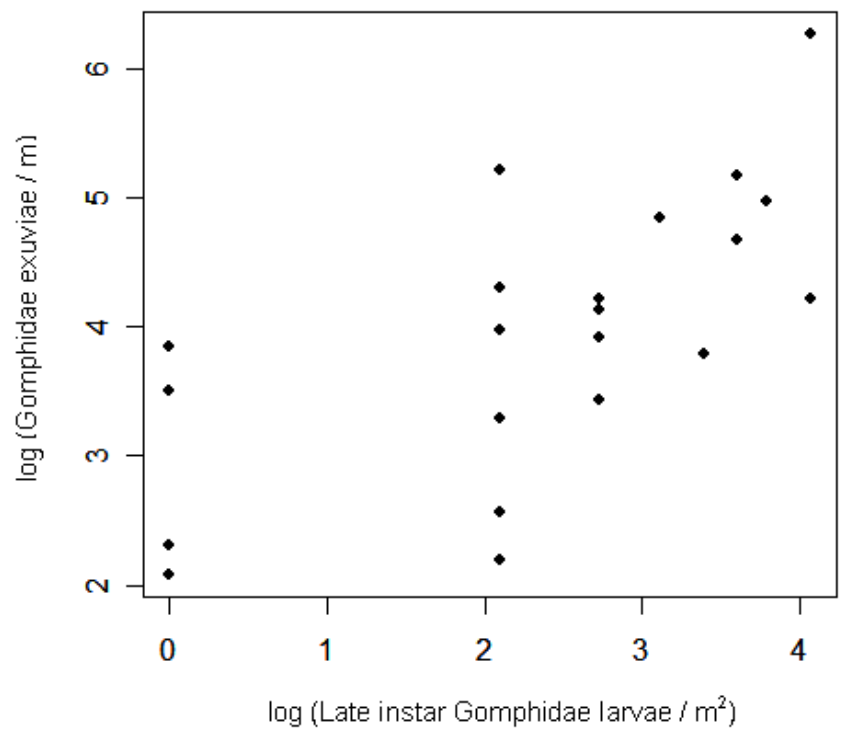

Two habitat variables improved the site-level regressions for Gomphidae densities when the previous life stages were included (Table 2). Of the four aquatic variables added to the model to predict early instar larval densities, only secchi depth contributed significantly in addition to previousyear adult densities (Table $1 ; \log \mathrm{L}=8.9, \mathrm{p}<0.01$, adj. $\mathrm{R}^{2}=0.50$ ). Secchi depth correlated negatively with larval density, indicating that larval densities were lower in lakes with clearer water. From the set of six candidate models for prediction of 2006 exuviae densities, only riparian tall wetland vegetation site length improved the model in addition to 2006 second-year larvae (Table 2; $\log \mathrm{L}=4.8, \mathrm{p}=0.03$, adj. $\mathrm{R}^{2}=0.86$ ). Thus sites with Carex, Typha, or Iris species covering more of the shoreline had higher densities of Gomphidae exuviae. With or without exuviae included in the models, none of the habitat variables explained very much variation in adult densities (Table 2).

\section{Discussion}

The concordance of Gomphidae densities across terrestrial-to-aquatic and aquatic-to-terrestrial transitions suggests that population dynamics of one life stage carry over to spatially separated life stages. A strong correlation between adult densities and early-instar larval densities suggests that early-instar larval distribution relates more to spatial variation in adults than to spatial variation in post-recruitment processes. The relationship is clearer when considering lake-level averages of adult and larval densities, possibly because breeding adult Gomphidae cover broader areas than the $30 \mathrm{~m}$ shoreline sites. Thus adult habitat selection behavior can play an important role in structuring aquatic communities, despite higher rates of mortality in larvae than in adults. Species-specific data on sex ratios and oviposition rates would be needed to confirm that oviposition relates directly to adult odonate densities. Studies using marked individuals [80] or microsatellite markers [18] provide clearest quantification of the percent of eggs that survive until adulthood. Despite absence of species data here, the strength of the correlations observed suggest that adult species observed were representative of the larval species composition. 
Most of the variation in exuviae densities among sites can be explained by site-level densities of the previous life stage, the late instar larvae. This finding supports the hypothesis that odonate larvae may not move very far during the weeks before they emerge [21], although species-specific movements were not tracked. The present surveys missed exuvia occurring several meters inland from the water's edge, noted for some Gomphus species [81], as well as the exuvia occurring so close to the water's edge that waves removed them. Nonetheless, the correlation documented here between larvae and exuvia suggests that surveys of Gomphidae exuviae may accurately represent the relative densities of late-instar larvae in the adjacent littoral zone. Even though larval odonate mortality may be highest during later instars [41,51,82] (but see [18]), the strength of the site-level correlation among stages suggests that spatial variation in larval predation is small relative to the variation in recruitment of late instar larvae. Inferences about predation on teneral dragonflies (immature adults that have recently shed their larval skins) cannot be made, though, because exuviae surveys reflect teneral densities only at the time of emergence, generally before predation has occurred on this life stage.

Absence of correlations between adult Gomphidae densities and corresponding exuviae densities or habitat variables probably reflects the high mobility and temporal variability of adults, along with a slightly smaller sample size for adult surveys. No significant correlation was observed between adult densities in 2005 and those in 2006 at the same sites. Sites on the same lakes did not even show any similarities in adult densities in 2006 (Table 3), despite surveys occurring on the same days within each lake. An additional factor confounding these results is that six Gomphidae species were included in this study, although G. spicatus was dominant. Behavior and survivorship may differ among species more in adults than in larvae. Thus results presented here may have missed concordance between exuviae and flying adults that is stronger in some species than others.

Secchi depth helped explain variation in larval densities, even though secchi depth was recorded at the lakes four years before these larval surveys. Lower larval densities in lakes with greater water clarity may result from improved visibility of odonates to their predators in these conditions $[45,83]$. The positive relationship between exuviae densities and abundance of riparian wetland vegetation suggests that emerging larvae preferentially seek areas with rigid stems on the shoreline for emergence, or that more larvae complete ecdysis successfully in these areas. However, Gomphidae also emerge successfully on horizontal structures, including the ground [63]. The rigid, vertical structures of wetland vegetation may offer emerging odonates protection from predators and/or less susceptibility to wind damage than tall grasses or shrubs [35]. Although all terrestrial variables were recorded during Odonata survey years, lake-level aquatic variables may have provided better predictive power if they were all recorded in the years of exuvia and larval surveys.

Riparian lawn sites did not appear to influence exuvia or adult Gomphidae densities at the spatial scale examined. Previous studies relating adult odonates to riparian vegetation indicated positive relationships between riparian woody vegetation and odonate species richness, but not odonate abundance $[32,34,84,85]$. Odonate species other than the Gomphidae considered here may therefore respond to lakeshore development. This study suggests that Gomphidae are more sensitive to water clarity, littoral macrophytes, and riparian wetland vegetation than to clearing of the forest understory to create lawns at some sites. However, water clarity, littoral macrophyte abundance, and riparian wetland vegetation abundance can each be reduced by the landscaping practices of riparian 
homeowners [59-61,86]. Manicured lawn sites in this study did not all have reduced macrophyte and riparian wetland plant abundances.

As changes are made to one or more habitats occupied by organisms with complex life cycles, understanding the relative influence of recruitment in each life stage can indicate how changes in one habitat affect other communities. This study provides novel evidence that adult Odonata site selection is a significant driver for spatial distribution of larval odonates. More empirical data on recruitment dynamics will be useful for many organisms with complex life cycles.

\section{Acknowledgements}

This research was supported by National Science Foundation (NSF) Biocomplexity Program DEB-0083545, North-temperate lakes Long Term Ecological Research, an NSF Graduate Research Fellowship, the Garden Club of America, and the Animal Behavior Society. M. Turner, B. Peckarsky, A. Ives, J. Zedler, C. Gratton, and S. Carpenter helped guide and critique the manuscript. M. Turner and staff at the University of Wisconsin Trout Lake station provided excellent logistical support. Thanks also to W. Smith for sharing expertise on Gomphidae behavior and to Bill Feeny for preparing Figure 1. M. Theis, P. Winkler, B. Henning, D. Hong, J. Iacarella, C. Leugers, and A. Duong helped collect data.

\section{References}

1. Ebenman, B.; Persson, L. Size-Structured Populations; Springer: New York, NY, USA, 1988.

2. Persson, L.; De Roos, A.M. Size-structured interactions and the dynamics of aquatic systems. Pol. J. Ecol. 2006, 54, 621-632.

3. Istock, C.A. Evolution of complex life cycle phenomena-An ecological perspective. Evolution 1967, 21, 592-605.

4. Moran, N.A. Adaptation and constraint in the complex life-cycles of animals. Annu. Rev. Ecol. Systemat. 1994, 25, 573-600.

5. Wilbur, H.M. Complex life cycles. Annu. Rev. Ecol. Systemat. 1980, 11, 67-93.

6. Werner, F.E.; Quinlan, J.A.; Lough, R.G.; Lynch, D.R. Spatially-explicit individual based modeling of marine populations: A review of the advances in the 1990s. Sarsia 2001, 86, 411-421.

7. Roughgarden, J.; Gaines, S.; Possingham, H. Recruitment dynamics in complex life cycles. Science 1988, 241, 1460-1466.

8. Hughes, T.P.; Baird, A.H.; Dinsdale, E.A.; Moltschaniwskyj, N.A.; Pratchett, M.S.; Tanner, J.E.; Willis, B.L. Supply-side ecology works both ways: The link between benthic adults, fecundity, and larval recruits. Ecology 2000, 81, 2241-2249.

9. Halpern, B.S.; Gaines, S.D.; Warner, R.R. Habitat size, recruitment, and longevity as factors limiting population size in stage-structured species. Am. Nat. 2005, 165, 82-94.

10. Mumby, P.J.; Edwards, A.J.; Arias-Gonzalez, J.E.; Lindeman, K.C.; Blackwell, P.G.; Gall, A.; Gorczynska, M.I.; Harborne, A.R.; Pescod, C.L.; Renken, H.; et al. Mangroves enhance the biomass of coral reef fish communities in the Caribbean. Nature 2004, 427, 533-536. 
11. Hellriegel, B. Single- or multistage regulation in complex life cycles: Does it make a difference? Oikos 2000, 88, 239-249.

12. Caudill, C.C. Empirical evidence for nonselective recruitment and a source-sink dynamic in a mayfly metapopulation. Ecology 2003, 84, 2119-2132.

13. Lobinske, R.J.; Stimack, J.L.; Ali, A. A spatially explicit computer model for immature distributions of Glyptotendipes paripes (Diptera: Chironomidae) in central Florida lakes. Hydrobiologia 2004, 519, 19-27.

14. Johannsson, O.E. Co-existence of larval Zygoptera (Odonata) common to the Norfolk Broads (U.K.). Oecologia 1978, 32, 303-321.

15. Thompson, D.J. The effects of survival and weather on lifetime egg-production in a model damselfly. Ecol. Entomol. 1990, 15, 455-462.

16. Wissinger, S.A. Spatial-distribution, life-history and estimates of survivorship in a 14-species assemblage of larval dragonflies (Odonata, Anisoptera). Freshwater Biol. 1988, 20, 329-340.

17. Johnson, D.H. The life history of Tegragoneuria cynosura (Say) in Bays Mountain Lake, Tennessee, United States (Anisoptera: Corduliidae). Odonatologica 1986, 15, 81-90.

18. Fincke, O.M.; Hadrys, H. Unpredictable offspring survivorship in the damselfly, Megaloprepus coerulatus, shapes parental behavior, constrains sexual selection, and challenges traditional fitness estimates. Evolution 2001, 55, 762-772.

19. Ubukata, H. Survivorship curve and annual flucturation in the size of emerging population of Cordulia aenea amurensis Selys (Odonata: Cordulidae). Jpn. J. Ecol. 1981, 31, 335-346.

20. Schaffner, A.K.; Anholt, B.R. Influence of predator presence and prey density on behavior and growth of damselfly larvae (Ischnura elegans) (Odonata: Zygoptera). J. Insect. Behav. 1998, 11, 793-809.

21. Ubukata, H. Oviposition site selection and avoidance of additional mating by females of the dragonfly, Cordulia aenea amurensis Selys (Corduliidae). Res. Popul. Ecol. 1984, 26, 285-301.

22. Alzmann, N.; Kohler, B.; Maier, G. Spatial distribution, food and activity of Gomphus pulchellus SELYS 1840 (Insecta; Odonata; Gomphidae) from a still water habitat. Int. Rev. Hydrobiol. 1999, 84, 299-313.

23. Stoks, R.; Johansson, F. Trading off mortality risk against foraging effort in damselflies that differ in life cycle length. Oikos 2000, 91, 559-567.

24. Stoks, R.; Block, M.D.; Meutter, F.V.D.; Johansson, F. Predation cost of rapid growth: behavioural coupling and physiological decoupling. J. Anim. Ecol. 2005, 74, 708-715.

25. Stoks, R.; McPeek, M.A. Predators and life histories shape Lestes damselfly assemblages along a freshwater habitat gradient. Ecology 2003, 84, 1576-1587.

26. Pfister, C.A. The role and importance of recruitment variability to a guild of tide pool fishes. Ecology 1996, 77, 1928-1941.

27. Forrester, G.E. Factors influencing the juvenile demography of a coral-reef fish. Ecology 1990, 71, 1666-1681.

28. Carchini, G.; Di Domenico, M.; Pacione, T.; Solimini, A.G.; Tanzilli, C. Species distribution and habitat features in lentic Odonata. Ital. J. Zool. 2003, 70, 39-46.

29. Foote, A.L.; Hornung, C.L.R. Odonates as biological indicators of grazing effects on Canadian prairie wetlands. Ecol. Entomol. 2005, 30, 273-283. 
30. McKinnon, B.; May, M.L. Mating habitat choice and reproductive success of Pachydiplax longipennis (Burmeister) (Anisoptera: Libellulidae). Advan. Odonatol. 1994, 6, 59-77.

31. Van Buskirk, J. Establishment and organization of territories in the dragonfly Sympetrum rubicundulum (Odonata, Libellulidae). Anim. Behav. 1986, 34, 1781-1790.

32. Hofmann, T.A.; Mason, C.F. Habitat characteristics and the distribution of Odonata in a lowland river catchment in eastern England. Hydrobiologia 2005, 539, 137-147.

33. Ward, L.; Mill, P.J. Habitat factors influencing the presence of adult Calopteryx splendens (Odonata: Zygoptera). Eur. J. Entomol. 2005, 102, 47-51.

34. Butler, R.G.; DeMaynadier, P.G. The significance of littoral and shoreline habitat integrity to the conservation of lacustrine damselflies (Odonata). J. Insect. Conserv. 2008, 12, 23-36.

35. Remsburg, A.J.; Turner, M.G. Aquatic and terrestrial drivers of dragonfly (Odonata) assemblages within and among north-temperate lakes. J. N. Amer. Benthol. Soc. 2009, 28, 44-56.

36. Resetarits, W.J. Oviposition site choice and life history evolution. Amer. Zool. 1996, 36, 205-215.

37. Buchwald, R. Vegetation and dragonfly fauna-Characteristics and examples of biocenological field studies. Vegetatio 1992, 101, 99-107.

38. Wildermuth, H. Habitat selection and oviposition site recognition by the dragonfly Aeshna juncea (L.): An experimental approach in natural habitats (Anisoptera: Aeshnidae). Odonatologica 1993, $22,27-44$.

39. Wildermuth, H. Habitate und habitatwahl der groben moosjungfer (Leucorrhinia pectoralis) Charp. 1825 (Odonata, Libellulidae). Z. Okol. Naturs. 1992, 1, 3-21.

40. Baird, J.M.; May, M.L. Foraging behavior of Pachydiplax longipennis (Odonata: Libellulidae). J. Insect. Behav. 1997, 10, 655-678.

41. Schutte, C.; Schridde, P.; Suhling, F. Life history patterns of Onychogomphus uncatus (Charpentier) (Anisoptera : Gomphidae). Odonatologica 1998, 27, 71-86.

42. Crowder, L.B.; Cooper, W.E. Habitat structural complexity and the interaction between bluegills and their prey. Ecology 1982, 63, 1802-1813.

43. Thompson, D.J. Regulation of damselfly populations: The effects of weed density on larval mortality due to predation. Freshwater Biol. 1987, 17, 367-371.

44. Diehl, S. Fish predation and benthic community structure-The role of omnivory and habitat complexity. Ecology 1992, 73, 1646-1661.

45. Aksnes, D.L.; Giske, J. A theoretical-model of aquatic visual feeding. Ecol. Model. 1993, 67, 233-250.

46. Wilson, K.A.; Magnuson, J.J.; Lodge, D.M.; Hill, A.M.; Kratz, T.K.; Perry, W.L.; Willis, T.V. A long-term rusty crayfish (Orconectes rusticus) invasion: dispersal patterns and community change in a north temperate lake. Can. J. Fisheries Aquat. Sci. 2004, 61, 2255-2266.

47. Bazzanti, M.; Della Bella, V.; Seminara, M. Factors affecting macroinvertebrate communities in astatic ponds in central Italy. J. Freshwater Ecol. 2003, 18, 537-548.

48. Suhling, F. Effects of fish on the microdistribution of different larval size groups of Onychogomphus uncatus (Odonata: Gomphidae). Arch. Hydrobiol. 1999, 144, 229-244.

49. Suhling, F. Spatial distribution of the larvae of Gomphus pulchellus Selys. (Anisoptera: Gomphidae). Advan. Odonatol. 1994, 6, 101-111. 
50. Mahato, M.; Johnson, D. Invasion of the Bays Mountain Lake dragonfly assemblage by Dromogomphus spinosus (Odonata, Gomphidae). J. N. Amer. Benthol. Soc. 1991, 10, 165-176.

51. Duffy, W.G. Demographics of Lestes disjunctus disjunctus (Odonata, Zygoptera) in a riverine wetland. Can. J. Zool. 1994, 72, 910-917.

52. Orians, G.H.; Wittenberger, J.F. Spatial and temporal scales in habitat selection. Am. Naturalist. 1991, 137, S29-S49.

53. Jakob, C.; Suhling, F. Risky times? Mortality during emergence in two species of dragonflies (Odonata: Gomphidae, Libellulidae). Aquat. Insect. 1999, 21, 1-10.

54. Gribbin, S.D.; Thompson, D.J. A quantitative study of mortality at emergence in the damselfly Pyrrhosoma nymphula (Sulzer) (Sygoptera: Coenagrionidae). Freshwater Biol. 1990, 24, 295-302.

55. Scheidler, M. Influence of habitat structure and vegetation architecture on spiders. Zool. Anz. 1990, 225, 333-340.

56. Langellotto, G.A.; Denno, R.F. Responses of invertebrate natural enemies to complex-structured habitats: A meta-analytical synthesis. Oecologia 2004, 139, 1-10.

57. Rehfeldt, G. Impact of predation by spiders on a territorial damselfly (Odonata: Calopterygidae). Oecologia 1992, 89, 550-556.

58. WDNR. Northern Wisconsin's Lakes and Shorelands: A Report Examining a Resource under Pressure; Wisconsin Department of Natural Resources: Madison, WI, USA, 1996.

59. Racey, G.D.; Euler, D.L. Small mammal and habitat response to shoreline cottage development in central Ontario. Can. J. Zool. 1982, 60, 865-880.

60. Radomski, P.; Goeman, T.J. Consequences of human lakeshore development on emergent and floating-leaf vegetation abundance. North Am. J. Fish. Manage. 2001, 21, 46-61.

61. Elias, J.E.; Meyer, M.W. Comparisons of undeveloped and developed shorelands, northern Wisconsin, and recommendations for restoration. Wetlands 2003, 23, 800-816.

62. Marburg, A.E.; Turner, M.G.; Kratz, T.K. Natural and anthropogenic variation in coarse wood among and within lakes. J. Ecol. 2006, 94, 558-568.

63. Corbet, P.S. Dragonflies: Behavior and Ecology of Odonata; Cornell University Press: Ithaca, NY, USA, 1999; p. 829.

64. Crowley, P.; Johnson, D. Co-occurrence of Odonata in the Eastern United States. Advan. Odonatol. 1982, 1, 15-37.

65. Burcher, C.L.; Smock, L.A. Habitat distribution, dietary composition and life history characteristics of odonate nymphs in a blackwater coastal plain stream. Amer. Midland Naturalist 2002, 148, 75-89.

66. Mead, K. Dragonflies of the North Woods. Kollath-Stensaas Publishing: Duluth, MN, USA, 2003; p. 203.

67. Rosenberg, J.; Pleski, J.; DuBois, R. Wisconsin Draonflies and Damselflies. Wisconsin Aquatic and Terrestrial Resources Inventory. Available online: http://wiatri.net/inventory/odonata/ index.cfm (accessed on 15 March 2011).

68. Peterson, G.D.; Beard, T.D.; Beisner, B.E.; Bennet, E.M.; Carpenter, S.R.; Cumming, G.S.; Dent, C.L.; Havlicek, T.D. Assessing future ecosystem services a case study of the Northern Highlands Lake District, Wisconsin. Conserv. Ecol. 2003, 7, 1-24. 
69. Lutz, P.E.; Pittman, A.R. Some ecological factors influencing a community of adult Odonata. Ecology 1970, 51, 279-284.

70. Moore, N.W.; Corbet, P.S. Guidelines for monitoring dragonfly populations. J. Br. Dragonfly Soc. 1990, 6, 21-23.

71. Walpole, M.J.; Sheldon, I.R. Sampling butterflies in tropical rainforest: An evaluation of a transect walk method. Biol. Conserv. 1999, 87, 85-91.

72. Pollard, E. A method for assessing changes in the abundance of butterflies. Biol. Conserv. 1977, 12, 115-134.

73. Caudill, C.C. The Metapopulation Biology of the Mayfly Callibaetis Ferrugineus Hageni in High Elevation Beaver Ponds; PhD Dissertation; Cornell University: Ithaca, NY, USA, 2002.

74. Carpenter, S.R.; Kratz, T.K.; Kitchell, J.; Magnuson, J.J.; Vander Zanden, M.J. Biocomplexity; Coordinated Field Studies; University of Wisconsin Board of Regents: Madison, WI, USA, 2006.

75. Olden, J.D.; McCarthy, J.M.; Maxted, J.T.; Fetzer, W.W.; Vander Zanden, M.J. The rapid spread of rustry crayfish (Orconectes rusticus) with observations on native crayfish declines in Wisconsin (U.S.A.): Trends over the past 130 years. Biol. Invasions. 2006, 8, 1621-1628.

76. Gergel, S.E. Scale-Dependent Landscape Effects on North Temperate Lakes and Rivers; M.Sc. Thesis; University of Wisconsin: Madison, WI, USA, 1996.

77. McCune, B.; Grace, J.B. Analysis of Ecological Communities; MjM Software Design: Gleneden Beach, OR, USA, 2002; p. 300.

78. Burnham, K.P.; Anderson, D.R. Model Selection and Multimodel Inference: A Practical Information-Theoretic Approach, 2nd ed.; Springer: New York, NY, USA, 2002; p. 488.

79. R Core Development Team. R: A Language and Environment for Statistical Computing, 2.4.1; $\mathrm{R}$ Foundation for Statistical Computing: Vienna, Austria, 2006. Available online: http://www.R-project.org (accessed on 20 October 2006).

80. De Block, M.; Stoks, R. Fitness effects from egg to reproduction: Bridging the life history transition. Ecology 2005, 86, 185-197.

81. Corbet, P.S. A Biology of Dragonflies; H.F. \& G. Witherby Ltd.: London, UK, 1962; p. 247.

82. Martin, T.H.; Johnson, D.M.; Moore, R.D. Fish-mediated alternative life-history strategies in the dragonfly Epitheca cynosura. J. N. Amer. Benthol. Soc. 1991, 10, 271-279.

83. Davies-Colley, R.J.; Smith, D.G. Turbidity, suspended sediment, and water clarity: A review. J. Am. Water Resour. Assoc. 2001, 37, 1085-1101.

84. Sahlen, G. The impact of forestry on dragonfly diversity in central Sweden. Int. J. Odonatol. 1999, 2, 177-186.

85. Rith-Najarian, J. The influence of forest vegetation variables on the distribution and diversity of dragonflies in a northern Minnesota forest landscape: A preliminary study (Anisoptera). Odonatologica 1998, 27, 335-351. 
86. Carpenter, S.R.; Benson, B.J.; Biggs, R.; Chipman, J.W.; Foley, J.A.; Golding, S.A.; Hammer, R.B.; Hanson, P.C.; Johnson, P.T.J.; Kamarainen, A.M.; et al. Understanding regional change: A comparison of two lake districts. Bioscience 2007, 57, 323-335.

(C) 2011 by the authors; licensee MDPI, Basel, Switzerland. This article is an open access article distributed under the terms and conditions of the Creative Commons Attribution license (http://creativecommons.org/licenses/by/3.0/). 